\title{
Abnormal Bactericidal, Metabolic, and Lysosomal Functions of Chediak-Higashi Syndrome Leukocytes
}

\author{
Richard K. Root, Alan S. Rosenthal, and Dominic J. Balestra \\ From the Laboratory of Clinical Investigation, National Institute of \\ Allergy and Infectious Diseases, National Institutes of Health, \\ Bethesda, Maryland 20014
}

\begin{abstract}
A B S T R A C T Phagocytic, antimicrobial, and metabolic functions were studied in leukocytes obtained from three patients with the Chediak-Higashi syndrome ( $\mathrm{CHS}$ ) and compared to normals, individuals, heterozygous for Chediak-Higashi syndrome, and two subjects with chronic granulomatous disease of childhood (CGD). Chediak-Higashi syndrome leukocytes showed normal ingestion of a variety of bacteria, Candida albicans, and polystyrene latex particles. Intracellular destruction was significantly impaired for Staphylococcus aureus, Group D streptococci, and a rough strain of Type II pneumococci over a $2 \mathrm{hr}$ incubation. Killing of Serattia marcescons was consistently delayed at $1 \mathrm{hr}$ whereas that of Escherichia coli and $C$. albicans appeared normal, unless the incubations were shortened to $20 \mathrm{~min}$. Examination of the rates of killing indicated that the greatest defect occurred in the first $20 \mathrm{~min}$ of contact between ChediakHigashi syndrome cells and bacteria. Separation of Chediak-Higashi syndrome granulocytes from monocytes revealed that the former were most defective in bactericidal activity. After phagocytosis, Chediak-Higashi syndrome granulocytes displayed a normal burst in oxygen consumption and oxidation of glucose $-1{ }^{14} \mathrm{C}$ and glucose$6-{ }^{14} \mathrm{C}$ and formate $-{ }^{14} \mathrm{C}$. Oxidation of glucose- $1-{ }^{14} \mathrm{C}$ by nonphagocytizing Chediak-Higashi syndrome granulocytes and monocytes averaged 2-3 times normal, whereas glucose- $6-{ }^{14} \mathrm{C}$ and formate- ${ }^{14} \mathrm{C}$ oxidation were not significantly increased by resting cells. Iodination of intracellular protein by Chediak-Higashi syndrome leukocytes
\end{abstract}

Dr. Root's present address is Infectious Disease Section, Department of Medicine, University of Pennsylvania, 552 Johnson Pavilion, Philadelphia, Pa. 19104.

An abstract of this report has been published in Clin. Res., April 1971 and portions were reported at the annual meeting of the American Federation for Clinical Research on 1 May 1971.

Received for publication 26 March 1971 and in revised form 28 July 1971. was significantly increased above normal in both the resting and phagocytizing state. Electron microscopic histochemistry revealed that almost all peroxidase activity was localized to the giant granules in ChediakHigashi granulocytes, and after bacterial ingestion there was a failure of delivery of peroxidase to many phagosomes. Upon longer incubation more phagosomes acquired peroxidase activity, presumably through a fusion process, although many giant granules remained intact. The contrasting patterns and kinetics of the killing defects and the differing metabolic properties of Chediak-Higashi syndrome and chronic granulomatous disease leukocytes emphasize the pleiomorphic nature of inherited disorders of leukocyte function.

\section{INTRODUCTION}

The Chediak-Higashi syndrome $(\mathrm{CHS})^{1}$ is a rare autosomal recessive disorder characterized by partial oculocutaneous albinism and the presence of giant abnormal lysosomes in most granule-containing cells (1). A similar disorder has been described in mink and cattle (1), and more recently in mice (2). A major clinical manifestation of this disease in affected patients is the occurrence of multiple bacterial infections, principally with Gram-positive organisms and, in particular, Staphylococcus aureus (3). Such infections are a major cause of death in this disease. Until recently (4), extensive studies in mink and cattle (5) failed to determine the mechanisms responsible for this decreased resistance to infection and the few reported investigations of patients

${ }^{1}$ Abbreviations used in this paper: BSA, bovine serum albumin; CGD, chronic granulomatous disease; CHS, Chediak-Higashi syndrome; HBSS, Hanks's balanced salt solution; HMS, hexose monophosphate shunt; MHS, modified Hanks's solution; NBT, nitroblue tetrazolium; PBS, phosphate-buffered saline; PMN, polymorphonuclear leukocytes; PSB, polystyrene balls; WBC, white blood cells. 
$(1,6-8)$ including leukocyte bactericidal assays in one individual (8) were likewise unrevealing.

Four patients with the CHS from three different families have been available for study at the National Institutes of Health since 1967. Previous investigations (9) have confirmed normal immunoglobulin levels (save for patients in the advanced stage of illness), normal antibody formation, delayed hypersensitivity, and reticuloendothelial clearance functions previously reported for other similarly affected patients $(6-8)$. Studies of leukocyte functions have documented the occurrence of neutropenia and decreased marrow granulocyte responses (10), diminished granulocyte responses to infection (9), impaired skin window migration and chemotactic responsiveness of their granulocytes (11), all of which might be incriminated in the pathogenesis of decreased host resistance. The present report deals with the phagocytic, bactericidal, and fungicidal properties of leukocytes obtained from three of these patients. In addition, data is presented on metabolic functions important to antimicrobial activity, as well as histochemical electron microscopic studies of lysosomal degranulation. The findings indicate that such leukocytes have defective bactericidal capabilities for a variety of bacteria which are most pronounced for $S$. aureus, streptococci, and pneumococci and can be characterized primarily as a delay in intracellular killing. Comparative studies with leukocytes obtained from two children with chronic granulomatous disease of childhood (CGD) suggest that this diminished antibacterial capacity is not due to metabolic deficiencies related to the generation of hydrogen peroxide but rather to abnormal lysosomal degranulation.

\section{METHODS}

CHS patients. Two male siblings and one female formed the CHS study group. Some clinical features of all have been previously published by others $(12,13)$. The female, presently $8 \mathrm{yr}$ of age, is in the accelerated or lymphomatous phase of the disease (1). This phase is characterized by varying degrees of granulocytopenia, anemia, thrombocytopenia, and mononuclear cell infiltration of organs with hepatosplenomegaly and lymphadenopathy (1). Intermittent therapy with corticosteroids and vincristine has been required for control of the manifestations of hypersplenism and organ invasion. Whenever possible, studies were performed when she was infection-free and not receiving steroids, and at least 3 wk after her last dose of vincristine. Because of the complicating factor of this type of chemotherapy, the majority of investigations were performed on the two male siblings (La. R., aged 18, and Le R., 19), both of whom are hematologically normal save for mild granulocytopenia and clinically well with the exception of recurrent sinopulmonary and skin infections. Neither patient has required corticosteroid and vincristine therapy and all studies were performed when they were free of infection.

CGD patients. Two males (S. E., aged 9, and B. P., 5), with typical sex-linked CGD, including histories of recurrent septic and granulomatous pulmonary lymph node and hepatic infections, and defective leukocyte bactericidal and respiratory capacities, were used for comparison. Some features of these patients have been reported $(14,15) .^{2}$ Studies were performed on these patients both when they were infected and clinically well. No significant alterations of the data presented were seen during infection.

Controls. Normal individuals of both sexes aged 10-35, parents of the male CHS patients, and a $65 \mathrm{yr}$ old female with bronchiectasis served as controls. All normal subjects were in good health at the time of study and none had a history of increased susceptibility to infection.

Separation of leukocytes. Erythrocytes were removed from heparinized $(10 \mathrm{U} / \mathrm{ml})$ venous blood by dextran sedimentation followed by hypotonic lysis (16). The remaining leukocytes were collected by low speed centrifugation (150 g for $7 \mathrm{~min})$ and washed twice in modified Hanks's solution (MHS) (17) with or without $10 \%$ heat-inactivated fetal calf serum. Total and differential leukocyte counts were performed by hemocytometer or electronic particle counter (Coulter Electronics, Inc., Hialeah, Fla.) and examination of Wright's stained smears, respectively. To obtain leukocyte preparations containing a high percentage of polymorphonuclear cells (92-96\%), a minor modification of the Ficoll-Hypaque (Pharmacia, Uppsala, Sweden) density gradient centrifugation technique of Boyum (18) followed by dextran sedimentation was employed. Heparinized blood was diluted 2:1 with isotonic saline, layered in $15-\mathrm{ml}$ volumes on $3 \mathrm{ml}$ of the Ficoll-Hypaque mixture, and centrifuged at $400 \mathrm{~g}$ for $40 \mathrm{~min}$ at $20^{\circ} \mathrm{C}$. After removal of the mononuclear cell layer $1 \mathrm{ml}$ of homologous or AB plasma was added to the erythrocyte-granulocyte pellet and the mixtures pooled. An equivalent volume of $3 \%$ dextran was added and after sedimentation of the erythrocytes, the granulocytes were obtained as noted above. Mononuclear cells obtained from the gradient were washed twice in MHS-10\% fetal calf serum and the percentage of monocytes determined by Wright's staining and ingestion of $0.01 \%$ neutral red dye. Before use, cells were suspended in Hanks's balanced salt solution (HBSS) at a concentration of $10 \times 10^{6}$ phagocytes (PMN plus monocytes) $/ \mathrm{ml}$. Viability as determined by $0.1 \%$ trypan blue dye exclusion was $>99 \%$ in all preparations examined.

Microorganisms. Representative Gram-positive organisms included a Staphylococcus aureus (phage type 29), a rough Type II pneumococcus, a Group D streptococcus, and a Bacillus subtilis. Gram-negative organisms included Escherichia coli and Serattia marcescens. The fungus employed was a Candida albicans type A. $^{3}$ All bacteria were grown overnight in trypticase soy or Todd-Hewitt broth (pneumococci), centrifuged for $20 \mathrm{~min}$ at $2000 \mathrm{~g}$, washed once in MHS, and adjusted to an approximate concentration of $1 \times 10^{8} / \mathrm{ml}$ turbidometrically with a Coleman (Coleman In-

${ }^{2}$ Ward and Schlegel (14) felt that patient B. P. did not have typical CGD because of the absence of a killing defect for Staphylococcus aureus. This finding was not confirmed in the present study and additional data to be noted below together with intermediate abnormalities found for the mother indicate that this patient is indeed a typical CGD child.

${ }^{3}$ Micro-organisms were kindly provided as follows: $S$. aurcus, Group D streptococci, E. coli, and $S$. marcescens by Dr. James MacLowery, National Institutes of Health, Clinical Center; the pneumococcus by Dr. W. Barry Wood, Jr., Johns Hopkins University, School of Medicine; the $B$. subtilis by Dr. William Davis, Washington State University, School of Veterinary Medicine; and the $C$. albicans by Dr. Martin Cline, University of California at San Francisco, School of Medicine. 
struments, Maywood, Ill.) Junior spectrophotometer set at $650 \mathrm{~m} \mu$. C. albicans was grown in Sabouraud's broth at $33^{\circ} \mathrm{C}$ overnight with agitation and allowed to stand several days at room temperature before use. The number of candida per milliliter was determined by counting in a hemocytometer. A portion was spun down at $2000 \mathrm{~g}$ for $10 \mathrm{~min}$ and brought up in HBSS at a concentration of $1 \times 10^{7} / \mathrm{ml}$.

Measurement of phagocytosis. Phagocytosis of microorganisms was determined in two ways. First, mixtures consisting of $5 \times 10^{6}$ phagocytes $/ \mathrm{ml}$ in $10 \% \mathrm{AB}$ serum-HBSS were incubated with viable and heat-killed organisms at $37^{\circ} \mathrm{C}$ with tumbling (Fisher Roto-Rack, Fisher Scientific Company, Pittsburgh, $\mathrm{Pa}$.) for $20 \mathrm{~min}$ and Wright's stained smears were made. The number of cells which had ingested one or more bacteria or candida were noted in counts of 100 200 phagocytes. Second, the kinetics of the phagocytic process by the entire cell population was determined by measuring the uptake of radiolabeled bacteria. S. aureus were labeled with ${ }^{14} \mathrm{C}$ by growing bacteria in trypticase soy broth to which either alanine- ${ }^{14} \mathrm{C}$ or mixed universally labeled $-{ }^{14} \mathrm{C}$ amino acids (New England Nuclear Corp., Boston, Mass.) were added in a concentration of $10 \mu \mathrm{Ci} / \mathrm{ml}$. ${ }^{14} \mathrm{C}$-labeled $E$. coli were similarly obtained by growing bacteria with thymidine $-{ }^{14} \mathrm{C}$ in trypticase soy broth at a concentration of 10 $\mu \mathrm{Ci} / \mathrm{ml}$. At the end of an overnight incubation at $37^{\circ} \mathrm{C}$ the bacteria were killed by placement in a boiling water bath for $20 \mathrm{~min}$, washed three times in saline by centrifugation at $2000 \mathrm{~g}$ for $20 \mathrm{~min}$ and adjusted to a final concentration of $5 \times 10^{8} / \mathrm{ml}$ in saline. ${ }^{14} \mathrm{C}$-labeled $S$. aureus obtained in this way conntained approximately $250,000-350,000 \mathrm{cpm} / \mathrm{ml}$ and E. coli $60,000-80,000 \mathrm{cpm} / \mathrm{ml}$. They were stored at $4^{\circ} \mathrm{C}$ until used, which was always within 3 wk after preparation.

Phagocytosis of the ${ }^{14} \mathrm{C}$-labeled bacteria by cells in suspension was determined by tumbling at $37^{\circ} \mathrm{C} 5 \times 10^{\circ}$ phagocytes in $1 \mathrm{ml}$ of $10 \%$ AB serum-HBSS in $12 \times 75 \mathrm{~mm}$ plastic tubes (Falcon Plastics, Div. of B-D Laboratories, Inc., Los Angeles, Calif.). At successive time intervals ingestion was halted by the addition of $10^{-2} \mathrm{M}$ sodium fluoride and placing the tubes in ice. Noningested bacteria were separated from the leukocytes by centrifugation at $4^{\circ} \mathrm{C}$ at $100 \mathrm{~g}$ for $10 \mathrm{~min}$ followed by two washes and repeated centrifugation using $4 \mathrm{ml}$ of $10 \%$ fetal calf serum in MHS containing $10^{-2} \mathrm{M} \mathrm{NaF}$. The resulting leukocyte pellets were allowed to dry overnight and digested the following day with $0.5 \mathrm{ml}$ of $0.2 \mathrm{~N} \mathrm{NaOH}$ for at least $2 \mathrm{hr}$ at $56^{\circ} \mathrm{C}$. The solutions were neutralized at the end of the digestion with $0.2 \mathrm{ml}$ of $3 \%$ glacial acetic acid, $0.5 \mathrm{ml}$ of distilled water was added, and $1 \mathrm{ml}$ portions counted in $10 \mathrm{ml}$ of Aquasol (New England Nuclear Corp., Boston, Mass.) in a scintillation counter (Packard Tri-Carb, Packard Instrument Co., Inc., Downers Grove, Ill.).

To measure phagocytosis by monolayers, preparations of granulocytes or monocytes $\left(4-5 \times 10^{6}\right.$ cells in $2 \mathrm{ml}$ of $10 \%$ fetal calf or AB serum-HBSS) were placed in $35 \mathrm{~mm}$ plastic Petri dishes (Falcon Plastics, Los Angeles, Calif.), and allowed to adhere at $37^{\circ} \mathrm{C}$ for $90 \mathrm{~min}$. At the end of the time nonadherent cells were removed by four gentle washes with warm HBSS and final incubation mixtures prepared using 2 -ml volumes of $10 \%$ AB serum-HBSS. ${ }^{14} \mathrm{C}$-labeled bacteria were added and the monolayers incubated at $37^{\circ} \mathrm{C}$. At different times phagocytosis was stopped by pouring off the supernates and gently washing four times with warm HBSS. The monolayers were allowed to dry and then digested with $\mathrm{NaOH}$, neutralized, and counted as above. In some experiments, portions were saved for the determination of protein content by the Lowry technique (19). The mono- layers could also be examined microscopically after staining with Wright's stain.

Antimicrobial assay's. For bactericidal studies, a modification of the technique of Hirsch and Strauss (20) was employed. Duplicate suspensions containing 5-10 $\times 10^{8}$ phagocytes in $10 \% \mathrm{AB}$ or autologous serum and HBSS were established in siliconized $13 \times 100 \mathrm{~mm}$ glass or $12 \times 75 \mathrm{~mm}$ plastic tubes and incubated at $37^{\circ} \mathrm{C}$ for $5-10 \mathrm{~min}$ before the addition of $0.1 \mathrm{ml}$ of the bacterial suspension. The tubes were then rotated end over end at $37^{\circ} \mathrm{C}$. Portions $(0.01$ or $0.001 \mathrm{ml}$ ) were removed at intervals using a calibrated platinum loop and placed in distilled water containing $0.01 \%$ human serum albumin to rupture the cells for total viable bacterial counts. For extracellular counts the majority $(>95 \%)$ of the leukocytes was deposited by centrifugation at $150 \mathrm{~g}$ for $5 \mathrm{~min}$ at $4^{\circ} \mathrm{C}$ and similar samples of the cell-free supernates removed and placed in isotonic saline. Serial 10 -fold dilutions were made and appropriate dilutions plated on trypticase soy agar. When pneumococci were used, $1.0 \mathrm{ml}$ of rabbit blood was added to each plate to facilitate growth. The plates were incubated at $37^{\circ} \mathrm{C}$ and the number of colonies counted the following day to determine the number of viable bacteria present at each time interval. Zero time counts were obtained by taking the mean of three suspensions which did not contain cells and which had been handled in a similar manner.

In some experiments a modification of the technique of Holmes, Quie, Windhorst, and Good (21) was used to determine the number of intracellular bacteria present. After a $20 \mathrm{~min}$ period of incubation to permit the completion of phagocytosis, streptomycin $(50 \mu \mathrm{g} / \mathrm{ml})$ and penicillin (100 $\mu \mathrm{g} / \mathrm{ml}$ ) were added to the medium after a portion was removed for the determination of total and leukocyte-associated bacteria. At suitable time intervals thereafter, additional $0.5-\mathrm{ml}$ portions were taken from the $2.0 \mathrm{ml}$ mixture, centrifuged at $150 \mathrm{~g}$ at $4^{\circ} \mathrm{C}$ and washed twice with $4 \mathrm{ml} 10 \%$ fetal calf serum-MHS. $5 \mathrm{ml}$ of distilled water was then added to lyse the leukocytes and pour plates were made to determine the remaining viable bacteria. The staphylococcus employed in these studies was penicillin-sensitive.

To evaluate candidacidal activity of cells the methylene blue vital staining technique of Lehrer and Cline (22) was employed without modification.

Oxygen consumption. Oxygen consumption was measured in triplicate or quadruplicate suspensions of $14-15 \times 10^{6}$ phagocytes using a Gilson (Gilson Medical Electronics, Inc. Middleton, Wis.) differential respirometer. All suspensions (2.0 $\mathrm{ml}$ total volume) were prepared in $15-\mathrm{ml}$ Warburg flasks to which were added leukocytes in HBSS, AB serum ( $25 \%$ final concentration), and $1.0 \mu$ polystyrene balls (PSB) (Dow Chemical Co., Midland, Mich.) diluted 1:5 with HBSS (approximately $2 \times 10^{\circ}$ total particles). All suspensions were incubated for at least $30 \mathrm{~min}$ before tipping in the PSB from the side arm to compare resting with phagocytizing responses.

Glucose oxidation. The oxidation of glucose labeled in the first or sixth position with ${ }^{14} \mathrm{C}$ was measured by a previously published technique (17). Suspensions of 5-10 $\times$ $10^{6}$ polymorphonuclear leukocytes in $2 \mathrm{ml}$ of $25 \% \mathrm{AB}$ serum-HBSS (11.2 $\mu$ moles and $0.5 \mu \mathrm{Ci}$ glucose) with and without PSB (approximately $2 \times 10^{\circ}$ ) were prepared. $\mathrm{CO}_{2}$ was trapped in $0.2 \mathrm{ml}$ of a $10 \%$ solution of $\mathrm{KOH}$ suspended from the rubber stopper in a plastic center well (Kontes Glass Co., Vineland, N. J.) after incubations of the suspensions for differing times and the addition of 0.5 $\mathrm{ml}$ of $1.0 \mathrm{~N} \mathrm{HCl}$. The well containing the $\mathrm{KOH}$ was then 
TABLE I

Differential Counts of Dextran-Separated Peripheral Leukocytes* from Normal and Chediak-Higashi Syndrome (CHS) Subjects

\begin{tabular}{lccccc}
\hline & \multirow{4}{*}{$\begin{array}{c}\text { Number of } \\
\text { preparations }\end{array}$} & PMN & Monocytes & Eosinophils & Lymphocytes \\
\cline { 3 - 6 } Subject & 33 & $56.4 \pm 1.7$ & $10.8 \pm 0.9$ & $4.5 \pm 1.0$ & $28.6 \pm 1.5$ \\
\hline L. R. & $P$ value & $<0.001$ & $<0.001$ & $>0.20$ & $<0.001$ \\
& 22 & $59.7 \pm 2.9$ & $9.7 \pm 1.1$ & $4.1 \pm 1.0$ & $26.0 \pm 2.7$ \\
La. R. & $P$ value & $<0.001$ & $<0.001$ & $>0.20$ & $<0.001$ \\
& 5 & $37.8 \pm 5.4$ & $11.2 \pm 2.2$ & $0.8 \pm 0.6$ & $50.2 \pm 5.3$ \\
T. H. & $P$ value & $<0.001$ & $<0.001$ & $>0.10$ & $<0.001$ \\
& & $<0.01 \S$ & $>0.20$ & $>0.10$ & $<0.001$ \\
& 57 & $81.8 \pm 1.3$ & $3.7 \pm 0.6$ & $4.2 \pm 0.7$ & $9.9 \pm 0.9$ \\
Normal & 57 & & & & \\
& & & &
\end{tabular}

* For details of separation procedure see text.

$\ddagger$ Two sample $t$ test compared with normal.

$\S$ Comparisons with other CHS subjects.

placed in $20 \mathrm{ml}$ of a scintillation solution (17) and counted for sufficient time to insure a counting error of $1.5 \%$ or less.

Formate oxidation. Hydrogen peroxide production by leukocytes was measured by the oxidation of formate- ${ }^{14} \mathrm{C}$ (23) in a manner similar to glucose oxidation with the following exceptions: $10 \times 10^{8}$ granulocytes were used routinely and 250 nmoles of cold sodium formate $\left(0.5 \mu \mathrm{Ci} \mathrm{Na}\right.$-formate- $\left.{ }^{14} \mathrm{C}\right)$ were added to the flasks in place of glucose ${ }^{14} \mathrm{C}$. Incubations were for $60 \mathrm{~min}$ at $37^{\circ} \mathrm{C}$ with trapping of $\mathrm{CO}_{2}$ and counting as described above. Cell-free controls were always prepared and the values for spontaneous formate oxidation subtracted from the preparations containing leukocytes.

Iodination of protein by leukocytes. The ability of leukocytes to iodinate intracellular protein precipitated by $10 \%$ trichloroacetic acid (TCA) in the resting state and with phagocytosis of heat-killed $S$. aureus was measured using a minor modification of the method of Klebanoff (24). Final suspensions in $12 \times 75 \mathrm{~mm}$ tubes contained $5 \times 10^{\circ} \mathrm{PMN}$, $10 \% \mathrm{AB}$ serum, $1 \times 10^{8}$ heat-killed $S$. aureus, 20 nmoles and $0.2 \mu \mathrm{Ci}$ of $\mathrm{Na}^{125} \mathrm{I}$ in $\mathrm{HBSS}$ (total volume $0.6 \mathrm{ml}$ ). These were incubated at $37^{\circ} \mathrm{C}$ with shaking for varying time intervals. The iodination reaction was halted by the addition of $0.01 \mathrm{~m}$ sodium thiosulfate and the tubes were placed on ice. $1 \mathrm{ml}$ of cold $10 \%$ TCA was added and the tubes centrifuged at $2000 \mathrm{~g}$ for $5 \mathrm{~min}$. The TCA precipitates were washed and centrifuged three times with cold $10 \%$ TCA and the ${ }^{125} \mathrm{I}$ in the pellet determined by placing each tube inside an $18 \times 150 \mathrm{~mm}$ tube and counting in a sodium iodide crystal well scintillation counter (Nuclear-Chicago Corporation, Des Plaines, Ill., model No. 4223). Appropriate cell-free suspensions were prepared with the TCA-precipitable counts in these added to background and subtracted from the resting and phagocytizing cell counts. In some experiments sodium azide $(0.01 \mathrm{~mm}$ final concentration) was added to the reaction mixtures to inhibit the peroxidase-mediated iodination reaction (25).

Nitroblue tetrazolium dye reduction. Quantitative measurement of the reduction of the colorless dye nitroblue tetrazolium to blue formazan was carried out using the technique of Baehner and Nathan (26).

Electron microscopic cytochemistry. $10 \times 10^{\circ}$ granuloctyes were incubated with a 100:1 ratio of heat-killed $S$. aureus in $1 \mathrm{ml}$ volumes of $10 \% \mathrm{AB}$ serum-HBSS at $37^{\circ} \mathrm{C}$ as above. At various times phagocytosis was halted and the cells fixed in suspension by the addition of $1 \mathrm{ml}$ of $2 \%$ gluteraldehyde in Tyrode's solution. The cells were washed in phosphatebuffered saline $\mathrm{pH} 7.4$ (PBS) and the cytochemical reaction product developed with $3,3^{\prime}$-diaminobenzidine for $30 \mathrm{~min}$ at room temperature (27). The cell suspension was then washed twice with PBS containing $10 \mathrm{~mm}$ potassium cyanide, suspended in $10 \%$ bovine serum albumin (BSA) and sedimented by centrifugation. After removal of the excess BSA, the cell pellet was gelled by the addition of $25 \mu \mathrm{l}$ of $8 \%$ gluteraldehyde and the pellet minced into $1 \mathrm{~mm}$ cubes. The cubes were then suspended in $1 \%$ osmic acid, dehydrated with ethanol, passed through propylene oxide and embedded in Maraglas (The Marblette Co., Div. Allied Products Corp., Long Island City, N. Y.). Thick sections were stained with toluidine blue and examined under the light microscope. Thin sections were stained with lead citrate and examined in a Philips (Philips Electronic Instruments, Mount Vernon, N. Y.) 300 electron microscope.

\section{RESULTS}

Differential counts of leukocyte preparations. In Table I differential counts of leukocytes prepared by the dextran sedimentation procedure are presented from the 3 CHS patients and 28 control subjects. All three patients were significantly neutropenic when compared to normal and had significantly higher mean percentages of monocytes and lymphocytes than the controls. The degree of the neutropenia of the two male siblings was mild compared to the female in the advanced stage of the CHS who had mean granulocyte percentages significantly below and lymphocyte percentages higher than both males. Eosinophil counts of all three $\mathrm{CHS}$ patients were not significantly different from normal. When cell preparations were equalized for phagocyte content in different studies, the mean percentage of granulocytes in the CHS phagocytic cell populations averaged from a low of $76.3 \%$ to a high of $81.3 \%$ in the bactericidal and 
TABLE II

Phagocytosis of Different Strains of Bacteria by Normal and Chediak-Higashi Syndrome (CHS) Leukocytes*

\begin{tabular}{|c|c|c|c|c|c|c|}
\hline \multirow[b]{2}{*}{ Organism } & \multirow[b]{2}{*}{ Subjectsł } & \multirow{2}{*}{$\begin{array}{c}\text { Number } \\
\text { experiments }\end{array}$} & \multirow{2}{*}{$\begin{array}{c}\text { Ratio } \\
\text { bacteria/cells } 8\end{array}$} & \multicolumn{2}{|c|}{ Phagocytosis\| } & \multirow{2}{*}{$\begin{array}{l}\text { Phagocytic } \\
\text { index }\end{array}$} \\
\hline & & & & Total & $>5$ & \\
\hline \multirow[t]{3}{*}{ S. aureus } & CHS (3) & 7 & $0.7-4.0 / 1$ & $71.5 \pm 6.2$ & $25.0 \pm 12.0$ & $3.0 \pm 0.3$ \\
\hline & Normal (5) & 6 & $0.7-4.0 / 1$ & $66.7 \pm 4.0$ & $14.0 \pm 4.0$ & $2.6 \pm 0.3$ \\
\hline & CHS-heterozygote $(2)^{* *}$ & 1 & $3 / 1$ & $63.0 \pm 1.0$ & $15.5 \pm 2.5$ & 一 \\
\hline \multirow[t]{2}{*}{ E. coli } & CHS (3) & 3 & $2.0 / 1$ & $58.0 \pm 8.9$ & - & $1.1 \pm 0.2$ \\
\hline & Normal & 3 & $2.0 / 1$ & $47.5 \pm 2.5$ & - & $1.0 \pm 0.1$ \\
\hline \multirow[t]{2}{*}{ S. marcescens } & CHS (3) & 3 & $1.0-10.0 / 1$ & $74.0 \pm 18.0$ & $49.0 \pm 23.5$ & - \\
\hline & Normal (2) & 2 & $1.0-10.0 / 1$ & $62.5 \pm 27.5$ & $39.0 \pm 38.0$ & - \\
\hline \multirow[t]{3}{*}{ Group D streptococci } & CHS (2) & 3 & $1.8-5.0 / 1$ & $55.5 \pm 3.0$ & $12.0 \pm 3.8$ & - \\
\hline & Normal (3) & 3 & $1.8-5.0 / 1$ & $51.5 \pm 5.2$ & $8.0 \pm 3.6$ & 一 \\
\hline & CHS-heterozygote (2) & 1 & $5 / 1$ & $45.5 \pm 12.5$ & $3.5 \pm 1.5$ & - \\
\hline \multirow{2}{*}{$\begin{array}{l}\text { Group D pneumoniae } \\
\quad \text { (R II36) }\end{array}$} & CHS (2) & 4 & $20.0 / 1$ & $95.0 \pm 2.0$ & $88.8 \pm 5.6$ & - \\
\hline & Normal (2) & 2 & $20.0 / 1$ & $95.5 \pm 0.5$ & 91.0 & - \\
\hline \multirow[t]{2}{*}{ B. subtilis } & CHS (2) & 4 & $1.0-3.0 / 1$ & $62.3 \pm 13.5$ & $24.5 \pm 13.4$ & - \\
\hline & Normal (2) & 2 & $1.0-3.0 / 1$ & $63.0 \pm 19.0$ & $24.5 \pm 21.5$ & 一 \\
\hline \multirow[t]{3}{*}{ S. albus } & CHS (3) & 8 & $5.0-10.0 / 1$ & $89.0 \pm 3.8$ & $76.0 \pm 2.3$ & 一 \\
\hline & Normal & 3 & $5.0-10.0 / 1$ & $92.7 \pm 5.4$ & $78.7 \pm 6.8$ & 一 \\
\hline & CHS-heterozygote (5) & 5 & $5.0-10.0 / 1$ & $90.6 \pm 1.6$ & $73.4 \pm 3.3$ & 一 \\
\hline
\end{tabular}

* Dextran-sedimented, washed leukocytes suspended in $10 \% \mathrm{AB}$ or homologous (S. albus) serum-HBSS at a concentration of $5 \times 10^{6}$ phagocytes per $\mathrm{ml}$ and incubated with tumbling at $37^{\circ} \mathrm{C}$ for $20 \mathrm{~min}$ with heat-killed or viable bacteria. For differential counts see text.

$\ddagger$ Numbers in parentheses refer to the number of subjects studied.

$\S$ Number of bacteria per phagocyte in initial inoculum, given as range in different experiments.

|| Per cent of granulocytes and monocytes containing one or more (total) and greater than five bacteria (100-200 cells counted). Results given as mean and standard error with principal variability due to wide range of inoculums employed.

T Mean number of intracellular bacteria per phagocyte. Results given as mean and standard error.

** Parents of CHS subjects.

phagocytic assays and from 76.0 to $86.1 \%$ in the metabolic studies. Similar values for normals ranged from 87.3 to $96.2 \%$. Monocytes as a percentage of total phagocytes in the CHS cell preparations varied from a low of 11.7 to $21.2 \%$ in the bactericidal assays and from 5.2 to $23.2 \%$ in the metabolic investigations vs. 0.2 to $7.5 \%$ for the normals. Despite these significant mean differences among both groups, granulocyte and monocyte percentages were occasionally the same for $\mathrm{CHS}$ and normal cells in some experiments.

Differential counts obtained from dextran-sedimented CGD leukocytes were in all cases similar to normal.

In contrast to these findings with dextran-sedimented cells, the Ficoll-Hypaque technique yielded equivalent populations of granulocytes from $\mathrm{CHS}$ and normal individuals with mean percentages ranging from 89.5 to $96.0 \%$ in different groups of experiments. Eosinophils made up the majority of the remaining cells. Mean monocyte and lymphocyte contamination was in all cases less than $2.5 \%$ and usually less than $2 \%$ for dif- ferent groups of experiments. Mononuclear cell preparations from the Ficoll-Hypaque gradients were likewise similar in both normal and $\mathrm{CHS}$ subjects with the percentage of monocytes ranging from a mean of 32.4 to $38 \%$, with lymphocytes making up the remainder of the cells. Granulocyte contamination of the mononuclear cell layer averaged less than $1 \%$ and usually was zero.

Phagocytosis. As indicated in Table II, phagocytosis of a variety of microorganisms by mixed leukocytes obtained from all three CHS subjects was similar to normal when evaluated microscopically regardless if the serum in the medium was homologous (experiments with Staphylococcus albus) or obtained from a common $A B$ pool to minimize variability due to differing opsonins. In all experiments in which a wide range of bacteria to cell ratios was utilized both the per cent of CHS phagocytes containing bacteria and the number of organisms per cell (phagocytic index) did not differ significantly from normal. 


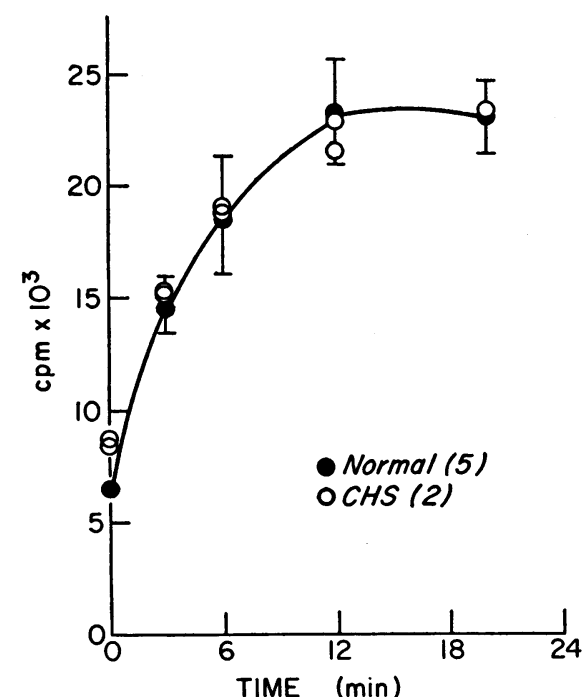

Figure 1 Phagocytosis of ${ }^{14} \mathrm{C}$-labeled $S$. aureus by mixed leukocytes from five normal and two $\mathrm{CHS}$ subjects. The line denotes the mean and the bars the standard error of the mean of the radioactivity (cpm) associated with the normal leukocyte pellets at each time interval. For leukocyte differential counts see text.

Phagocytosis by CHS monocytes appeared to be essentially similar to normal monocytes and was less than PMN when examined microscopically.

Data obtained on the kinetics of the ingestion process by measuring the uptake of ${ }^{14} \mathrm{C}$-labeled bacteria by cells in suspension or monolayers confirmed the microscopic observations of normal phagocytosis by the CHS leukocytes. In preliminary experiments it was determined that the number of counts associated with the leukocyte pellet was directly proportional to the number of intracellular organisms at each time interval. As shown in Fig. 1, which depicts the ingestion of ${ }^{14} \mathrm{C}$-labeled $S$. aureus by mixed populations of CHS and normal cells, the uptake of radioactivity by leukocytes from the two males was equivalent to the mean of five normal controls. Similar information was obtained when ${ }^{14} \mathrm{C}$-labeled $E$. coli were used and when granulocytes and mononuclear cells from one subject (Le. R.) separated by the Ficoll-Hypaque technique were studied in suspension. In fact, at early times phagocytosis by the CHS granulocytes appeared to be faster than normal (68\% for CHS vs. $57 \%$ uptake for normal cells at $5 \mathrm{~min}$ ). Uptake of ${ }^{14} \mathrm{C}$-labeled $S$. aureus by leukocytes in suspension from one CGD subject (B. P.) was equivalent to normal (data not shown).

A better examination of the phagocytic capabilities of monocytes was obtained by measuring the ingestion of ${ }^{14} \mathrm{C}$-labeled $S$. aureus in monolayers which had been washed free of most of the contaminating lymphocytes. As shown in Fig. 2 the mean ingestion rate of ${ }^{14} \mathrm{C}$ - labeled $S$. aureus by monocytes in two experiments from one patient (Le. R.) was greater than the mean of three normal controls; however, the differences were not statistically significant. It is noteworthy that the kinetics of the ingestion process was different by cells adherent to a plastic surface compared to those in suspension. The density of the cells on the monolayers appeared similar when examined microscopically and the values for cellular protein determined in one experiment were similar (mean $\mu \mathrm{g}$ protein/plate $=0.311$ for normal vs. 0.227 for $\mathrm{CHS}$ ).

Phagocytosis of ${ }^{14} \mathrm{C}$-labeled $S$. aureus by $\mathrm{PMN}$ in similarly prepared monolayers was suggestive of enhanced activity by CHS cells when compared to normal; however, the results obtained were quite variable due to variations in adherence of these cells to the plastic Petri dishes and therefore are inconclusive.

Bactericidal activity. The bactericidal activity of mixed CHS, CGD, and normal leukocytes against five different species of bacteria are shown in Table III. Since there were no significant differences among individual patients the data from each disorder has been pooled in comparing the patient groups against normal subjects. As expected, from previous studies (28) CGD leukocytes consistently showed impaired killing of the catalase-positive organisms, $S$. aureus, $E$. coli, and $S$. marcescens, as well as $C$. albicans (Fig. 3 ). Killing of the catalase-negative Group D streptococcus was normal at the 60 - and 120 -min time intervals studied. In contrast, CHS leukocytes displayed bactericidal defects for both catalase-negative and catalase-positive bacteria depending upon the time of incubation. For instance, kill-

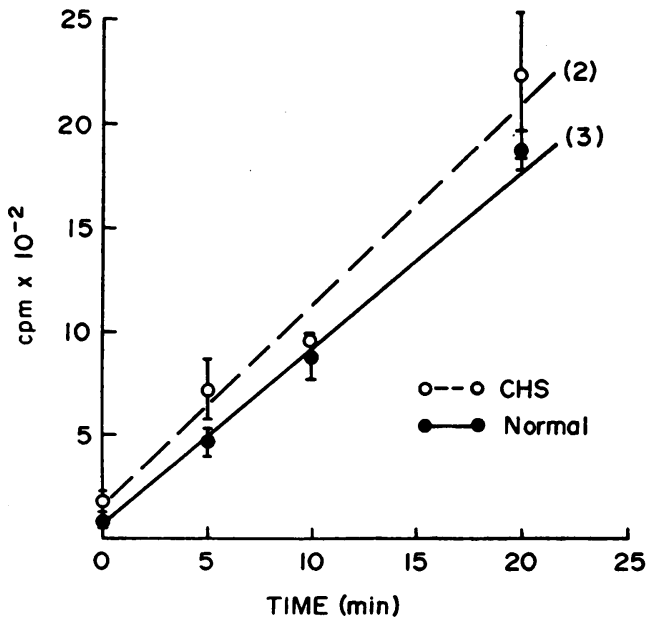

Figure 2 Phagocytosis of ${ }^{14} \mathrm{C}$-labeled $S$. aureus by monocytes adherent to plastic Petri dishes as a monolayer from three normal and one CHS subject (two experiments). The bars denote the standard error of the mean radioactivity (cpm) at each time interval as denoted by the open or closed circles. 
ing of $S$. aureus, rough pneumococci, and Group D streptococci was significantly less than normal through $2 \mathrm{hr}$ of incubation, whereas that of $S$. marcescens was less than normal at $1 \mathrm{hr}$ but not at $2 \mathrm{hr}$. Killing of $E$. coli was only significantly less than normal at the $20 \mathrm{~min}$ incubation time. Killing of a strain of $B$. subtilis for which leukocytes from $\mathrm{CHS}$ cattle have a bactericidal defect (4) was also less than normal in five out of eight experiments (data not shown) through $2 \mathrm{hr}$ incubation; however, because of variability the mean differences for all the studies were not statistically significant. Killing of $C$. albicans (Fig. 3) was less than normal at $60 \mathrm{~min}$ of incubation on one occasion only, with one of two CHS subjects. Consistent with the observations on phagocytosis noted previously, clearance of bacteria from the cell-free medium at $2 \mathrm{hr}$ was similar to normal in both patient groups. The majority of surviving bacteria for which defective killing was documented were therefore associated with the leukocyte pellets.

The differences in the kinetics of the killing process in the two types of patients compared to normal are shown in Fig. 4 which graphically depicts the survival of $S$. aureus over a $2 \mathrm{hr}$ incubation. Killing of the total inoculum by both CHS and CGD cells was similar over the first $20 \mathrm{~min}$ and significantly less than normal. After this time, killing by CHS leukocytes continued whereas that by the CGD cells halted after the initial $20 \mathrm{~min}$ incubation. Organisms within CHS leukocytes ("intra-

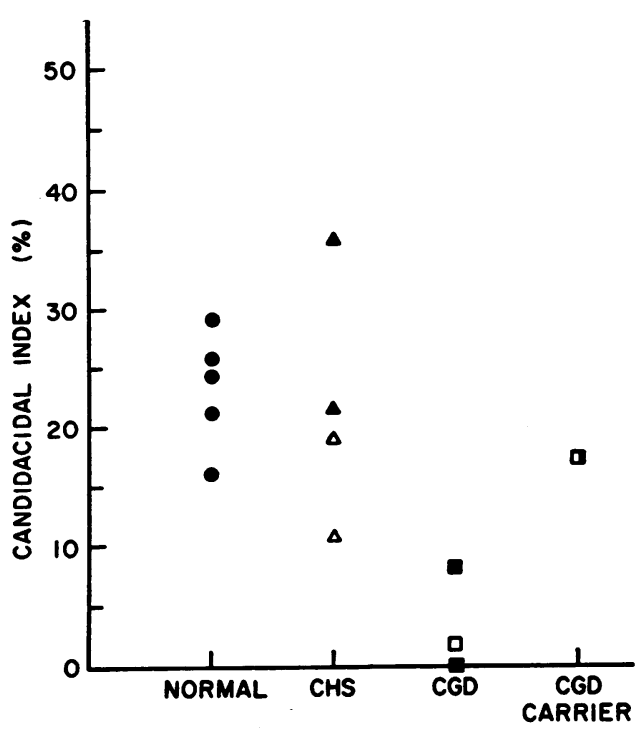

FIGURE 3 Comparative candidacidal activity of normal (O), CHS $(\Delta, \Delta)$, CGD $(\square, \square)$, and $q$ CGD carrier $(\square)$ subjects. The candidacidal index refers to the per cent of candida stained with methylene blue, $1 \mathrm{hr}$ after mixing cells $\left(2.5 \times 10^{6}\right)$ with fungi $\left(2.5 \times 10^{\circ}\right)$. All values represent the mean result of duplicate determinations ( 300 candida counted).

cellular") as determined after the addition of antibiotics were in fact killed at a rate equivalent to normal, although significantly more bacteria were present through

TABLE III

Bactericidal Activity of Leukocytes* from Normal, Chediak-Higashi Syndrome (CHS), and Chronic Granulomatous Disease (CGD) Subjects

\begin{tabular}{|c|c|c|c|c|c|c|c|c|c|c|}
\hline \multirow{3}{*}{$\begin{array}{l}\text { Organism } \\
\text { S. aureus }\end{array}$} & \multirow{5}{*}{$\begin{array}{l}\text { Subject } \\
\text { Normal (15)** } \\
\text { CHS (3) } \\
\text { CGD (2) }\end{array}$} & \multirow{3}{*}{$\begin{array}{c}\begin{array}{c}\text { Number } \\
\text { experiments }\end{array} \\
18\end{array}$} & \multirow{3}{*}{$\begin{array}{c}\begin{array}{c}\text { Inoculum! } \\
\times 10^{8}\end{array} \\
12.8 \pm 1.4\end{array}$} & \multicolumn{4}{|c|}{ Per cent survival\& } & \multirow{2}{*}{\multicolumn{2}{|c|}{$\begin{array}{l}\text { Cell-associated, } \| \\
120 \mathrm{~min}\end{array}$}} & \multirow{3}{*}{$\begin{array}{c}\begin{array}{l}\text { Per cent } \\
\text { cleared }\end{array} \\
\mathbf{9 8 . 3} \pm 0.8\end{array}$} \\
\hline & & & & \multirow{4}{*}{\begin{tabular}{l}
\multicolumn{1}{c}{$20 \mathrm{~min}$} \\
$25.4 \pm 4.6$ \\
$57.1 \pm 5.9 \ddagger \ddagger$ \\
$51.5 \pm 6.7 \ddagger \ddagger$
\end{tabular}} & \multirow{4}{*}{\begin{tabular}{l}
\multicolumn{1}{c}{$60 \mathrm{~min}$} \\
$12.4 \pm 3.5$ \\
$45.3 \pm 7.0 \ddagger \ddagger$ \\
$54.7 \pm 17.5 \ddagger \ddagger$
\end{tabular}} & \multicolumn{2}{|c|}{$120 \mathrm{~min}$} & & & \\
\hline & & & & & & 6.1 & \pm 1.6 & 5.6 & \pm 1.8 & \\
\hline & & 13 & $13.0 \pm 1.5$ & & & 25.2 & $\pm 6.1 \ddagger t$ & 23.6 & $\pm 5.1 \ddagger t$ & $98.4 \pm 1.1$ \\
\hline & & 5 & $15.4 \pm 5.7$ & & & 49.1 & $\pm 16.5 t \sharp$ & 45.5 & $\pm 14.6 \neq \ddagger$ & $95.9 \pm 1.8$ \\
\hline Group D streptococci & Normal (7) & 9 & $18.8 \pm 2.1$ & - & $1.2 \pm 0.2$ & 0.30 & \pm 0.18 & & 一 & - \\
\hline & CHS (2) & 5 & $19.3 \pm 3.5$ & - & $9.7 \pm 3.2 \ddagger \ddagger$ & 2.9 & $\pm 1.6 \pm t$ & & 一 & - \\
\hline & CGD (1) & 2 & $16.9 \pm 0.2$ & 一 & $1.6 \pm 0.6$ & 0.11 & \pm 0.04 & & 一 & 一 \\
\hline Group D pneumoniae & Normal (2) & 3 & $1.2 \pm 0.8$ & 一 & $3.6 \pm 0.6$ & 0.45 & \pm 0.10 & 0.26 & $6 \pm 0.09$ & $99.8 \pm 0.1$ \\
\hline (RII 36) & CHS (2) & 4 & $1.1 \pm 0.5$ & - & $21.6 \pm 9.0 \ddagger \ddagger$ & 6.9 & $\pm 1.6 \pm \sharp$ & 5.8 & $\pm 1.5 \ddagger$ & $98.9 \pm 0.3$ \\
\hline E. coli & Normal (11) & 9 & $9.6 \pm 0.5$ & $21.4 \pm 4.1$ & $3.2 \pm 1.1$ & 1.7 & \pm 0.5 & 1.8 & \pm 0.3 & $99.7 \pm 0.1$ \\
\hline & CHS (3) & 13 & $9.8 \pm 0.5$ & $54.5 \pm 12.5 \ddagger \ddagger$ & $8.0 \pm 1.8$ & 2.1 & \pm 0.7 & 1.3 & \pm 0.4 & $98.2 \pm 0.7$ \\
\hline & CGD (2) & 5 & $11.6 \pm 0.8$ & - & $17.9 \pm 5.0 \ddagger \ddagger$ & 18.3 & $\pm 6.1 \neq t$ & 15.1 & $\pm 5.2 \ddagger \ddagger$ & $96.6 \pm 1.3$ \\
\hline S. marcescens & Normal (5) & 12 & $19.7 \pm 3.7$ & 一 & $8.0 \pm 1.9$ & 3.2 & \pm 1.2 & 2.2 & \pm 0.9 & $99.0 \pm 0.5$ \\
\hline & CHS (3) & 12 & $24.2 \pm 4.1$ & - & $20.8 \pm 4.0 \ddagger \ddagger$ & 4.0 & \pm 1.1 & 2.2 & \pm 0.9 & $98.2 \pm 0.6$ \\
\hline & CGD (2) & 4 & $23.1 \pm 9.3$ & - & $29.9 \pm 9.6 \ddagger \ddagger$ & 15.7 & $\pm 5.6 \pm \ddagger$ & 10.7 & $\pm 2.8 \ddagger \ddagger$ & $95.0 \pm 2.8 \ddagger \ddagger$ \\
\hline
\end{tabular}

* Cells separated by dextran sedimentation (for differential counts see text) and incubated with bacteria in $10 \%$ AB serum-HBSS in a concentration of $5 \times 10^{6}$ phagocytes (PMN and monocytes)/milliliter.

\pm Number of viable organisms at zero time as determined by pour plate counts (mean $\pm \mathrm{SE}$ ).

Per cent survival (mean $\pm \mathrm{SE}$ ) of bacterial inoculum at time intervals noted.

$\|$ Per cent (mean $\pm \mathrm{SE}$ ) of original inoculum associated with leukocyte pellet after centrifugation at $150 \mathrm{~g}$.

T Per cent (mean $\mathrm{tSE}$ ) bacteria removed from cell-free supernate (150 g centrifugation) by adherence to or ingestion by leukocytes at 120 min.

** Number of different subjects studied.

\# Difference from normal statistically significant $(P<0.05$ or less two sample $t$ test).

Defective Bacterial Activity of Chediak-Higashi Syndrome Leukocytes 


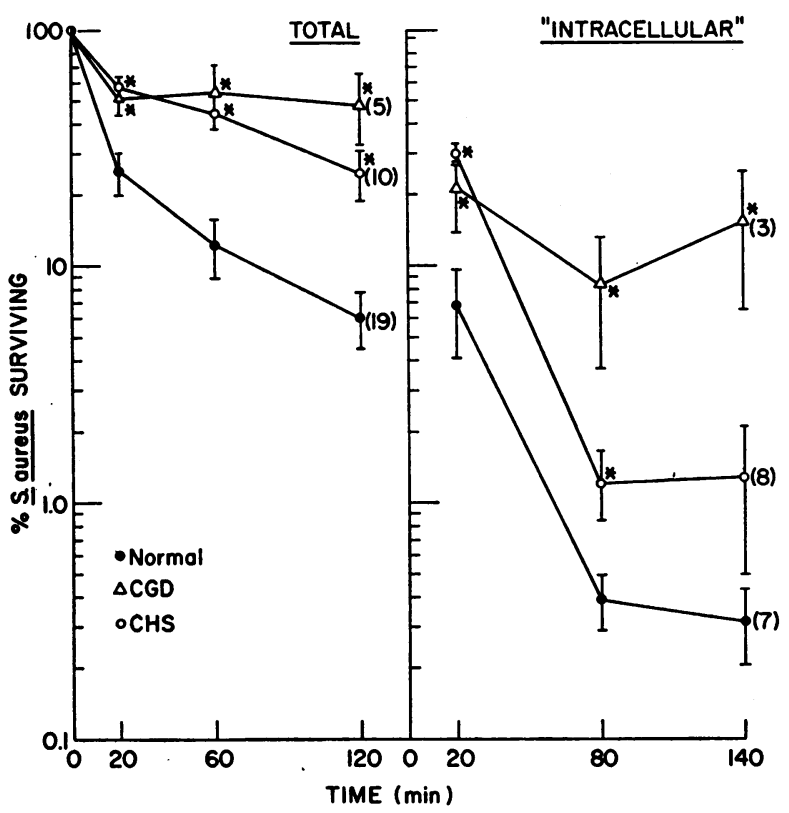

FIGURE 4 Comparative killing of staphylococci by mixed normal, CGD, and CHS leukocytes expressed as the per cent surviving viable bacteria with time. The number of experiments with $3 \mathrm{CHS}, 2 \mathrm{CGD}$, and 7 ("intracellular") to 15 ("total") normal subjects are shown in parentheses. The bars denote the standard error of the mean at each time interval. "Total" bacteria were determined by sampling portions of the entire leukocyte suspension. "Intracellular" bacteria refer to those organisms which remained after the addition of penicillin and streptomycin to the medium and washing the leukocyte pellets several times before sampling. Stars denote differences which are significant by two sample $t$ testing $(P<0.05$ or greater $)$.

$80 \mathrm{~min}$ due to the early lag in killing. By $140 \mathrm{~min}$, overlapping values for killing of intracellular $S$. aureus were seen in some experiments and when the incubations were prolonged through $4 \mathrm{hr}$ (data not shown), killing by CHS leukocytes in two experiments became equivalent to normal.

Comparison of antistaphylococcal action of CHS granulocytes and monocytes. Since, as noted above, the CHS-mixed phagocyte populations differed from normal in their greater content of monocytes it became desirable to examine separately the bactericidal properties of both monocytes and granulocytes. Fig. 5 demonstrates the antistaphylococcal activity of FicollHypaque-separated granulocytes and mononuclear cells, and indicates that killing is slightly but not significantly less for normal PMN obtained by this procedure when compared to dextran-separated cells. Killing by $\mathrm{CHS}$ granulocytes was found to be similar to the mixed cell population (5-6:1 PMN to monocytes) and was significantly less than normal through $2 \mathrm{hr}$ of incubation. In addition, killing by $\mathrm{CHS}$ monocytes also was delayed at $1 \mathrm{hr}$, becoming normal by $2 \mathrm{hr}$.
Comparative oxidative metabolism of CHS, CGD, and normal leukocytes. Oxygen consumption by mixed CHS leukocytes was greater than normal at rest and showed a marked increase with phagocytosis (Fig. 6). This contrasted sharply with similar studies with CGD cells, which as expected (29) showed no postphagocytic respiratory burst (data not shown).

Similar to these observations the oxidation of glucose$1-{ }^{14} \mathrm{C}$ by mixed $\mathrm{CHS}$ phagocytes was greater than normal in the nonphagocytic state at both 30 - and $60-\mathrm{min}$ incubation times (Table IV), although the differences were not statistically significant with the small number of experiments done. Postphagocytic activity was higher at $30 \mathrm{~min}$ in one experiment but equivalent to normal by $60 \mathrm{~min}$. CGD leukocytes demonstrated the previously observed (29) deficiencies in glucose oxidation via the

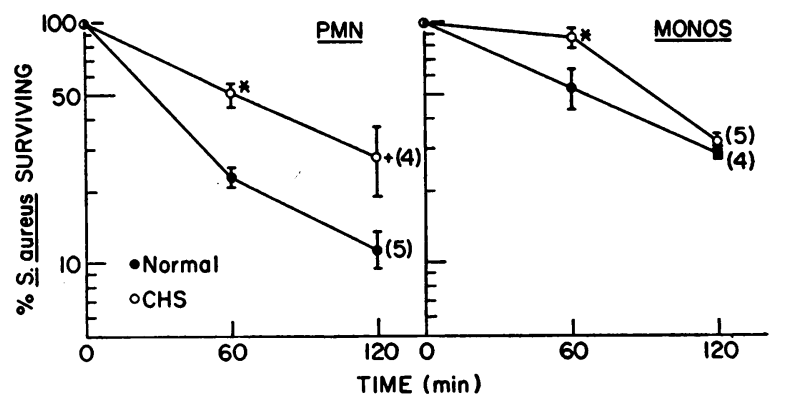

FIGURE 5 Antistaphylococcal activity of granulocytes (> $95 \%$ ) and mononuclear cells (30-35\% monocytes) separated by Ficoll-Hypaque gradient centrifugation as noted in the text. Numbers in parentheses refer to the number of experiments with two CHS and four normal subjects. The bars denote the standard error of the mean at each time interval. Symbols indicate differences that are significantly different $(P<0.05)$ by two sample $(*)$ or paired sample $(+) t$ tests.

hexose monophosphate shunt (HMS) both at rest and with phagocytosis.

These observations were extended to purified preparations of $\mathrm{PMN}$ and mononuclear cells and a larger number of experiments were performed. The pattern of greater activity by nonphagocytizing $\mathrm{CHS}$ leukocytes was found to exist both for PMN at 30- and 60min incubation times and mononuclear cells at $60 \mathrm{~min}$ whether in suspension or adherent to glass with contaminating lymphocytes removed (Table V). The differences were statistically significant. Postphagocytic oxidation of glucose- $1-{ }^{14} \mathrm{C}$, on the other hand, was similar to normal by CHS PMN at both 30 and $60 \mathrm{~min}$, whereas that by monocytes was greater than normal at the later incubation time. It is noteworthy that postphagocytic glucose-1- ${ }^{14} \mathrm{C}$ oxidation was significantly less for normal PMN obtained by the longer Ficoll-Hypaque separation procedure than by dextran sedimentation (Table IV) at the 60 min incubation time $(P<0.02$, 
$t$ test). Similar differences were found for the CHS leukocytes, but due to variability were not statistically significant.

The oxidation of glucose- $6-{ }^{14} \mathrm{C}$ and formate $-{ }^{14} \mathrm{C}$ by resting $\mathrm{CHS}$ leukocytes also averaged higher than normal but the differences were not statistically significant. Phagocytizing CHS granulocytes and mixed phagocytes were similar to normal in both these functions (Table IV). Again CGD leukocytes demonstrated the previously documented (29) deficiencies in formate oxidation.

Iodination of intracellular protein. In parallel with the findings on glucose oxidation by $\mathrm{CHS}$ leukocytes, intracellular iodination of protein, a myeloperoxidasemediated reaction (24), was greater than normal by resting cells (Table VI). In addition, higher postphagocytic values were observed, using heat-killed $S$. aureus as the phagocytic particle. The addition of $1 \mathrm{~mm}$ azide to the reaction mixtures resulted in equivalent suppression of both normal (97.8\%) and CHS (94.9\%) activities and placed them in the range of those found for the CGD leukocytes (30). Measurement of iodina-

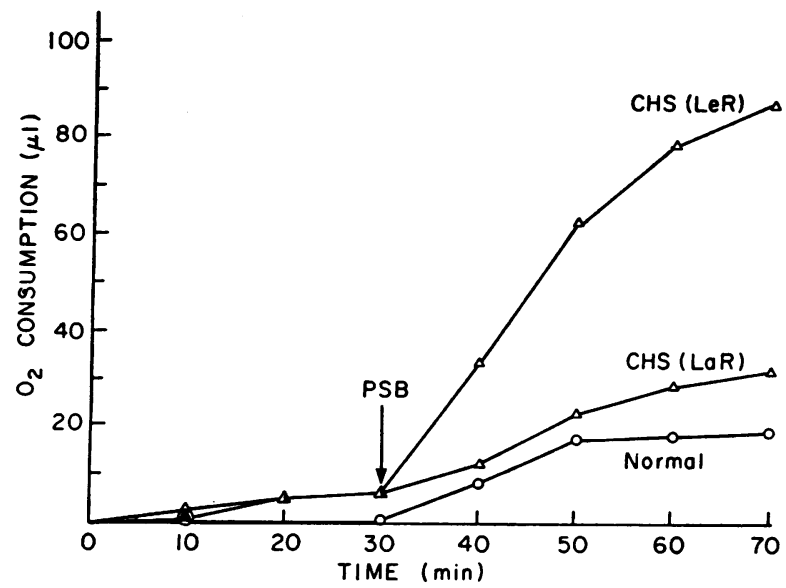

FIGURE 6 Oxygen consumption before and after the addition of polystyrene latex particles (PSB) to suspensions of mixed CHS (subjects Le. R. and La. R.) and normal leukocytes. Phagocytes numbered $14 \times 10^{\circ}$ in the mixtures and the lines represent the mean of triplicate determinations. The mean number of each cell type which made up the CHS phagocytic population was $76 \% \mathrm{PMN}, 23.2 \%$ monocytes, and $0.8 \%$ eosinophils vs. the normal values of $92.2 \% \mathrm{PMN}$, $0.2 \%$ monocytes, and $2.5 \%$ eosinophils.

tion at 10 - and 30 -min time intervals gave results similar to the above with CHS cells always exhibiting greater activity than normal (data not shown).

Phagocytic reduction of NBT dye. As shown in Fig. 7, CHS-mixed leukocytes were capable of normally reducing NBT due to blue formazan during phagocytosis of polystyrene latex particles. This repre- sented another differentiating feature of these cells when compared to CGD leukocytes.

Cytochemical analysis of degranulation by electron microscopy. Since the metabolic studies suggested that the observed bactericidal defects in CHS phagocytes could not be explained by a failure of peroxide formation or myeloperoxidase-mediated peroxidation, attention was turned to the postphagocytic degranulation process. In preliminary studies the microscopic observation, previously noted for $\mathrm{CHS}$ mink and cattle leukocytes (5), that the large granules persisted seemingly intact within $\mathrm{CHS}$ PMN for prolonged periods of time after phagocytosis of bacteria was confirmed. Evaluation with phase microscopy disclosed the presence of many of these granules around phagocytic vacuoles after ingestion of $S$. aureus, and in some cases apparent localization within phagosomes. Better morphological documentation of the degranulation process was obtained through the use of a cytochemical assay for peroxidase activity in conjunction with electron microscopy. In nonphagocytic $\mathrm{CHS}$ granulocytes almost all detectable peroxidase activity was localized to the giant granules (Fig. 8B), which are few in number when compared to the large peroxidase-positive primary granule population of normal PMN (Fig. 8A). 15 min after mixing with staphylococci, the differences in the appearance between intracellular bacteria in the two cell types was striking. Within normal granulocytes almost all phagocytic vacuoles were seen to contain peroxidase reaction product and the bacteria appeared to be undergoing degeneration (Figs. $8 \mathrm{C}$ and $\mathrm{D}$ ). In contrast, in CHS PMN many phagosomes contained no peroxidase activity and the bacteria within these retained their defining structural characteristics (Figs.

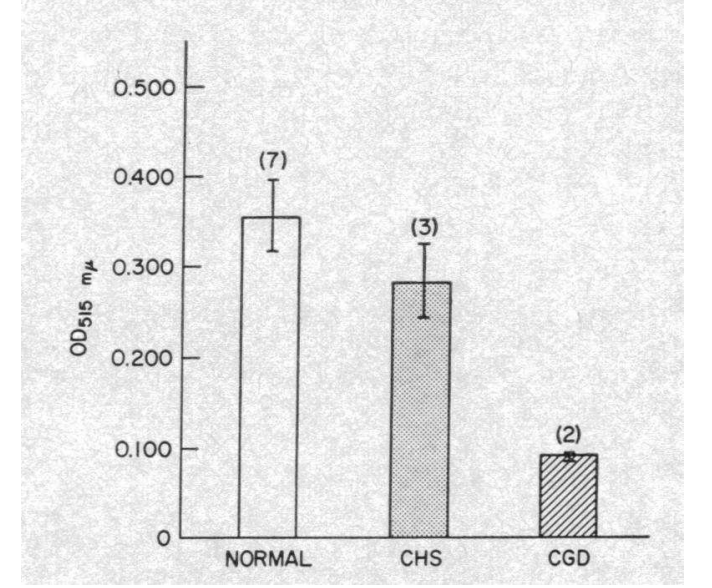

FIGURE 7 Quantitative reduction of nitroblue tetrazolium dye by $2.5 \times 10^{6}$ mixed phagocytes from seven normal, three CHS, and two CGD subjects after phagocytosis of polystyrene latex particles. Values given as the mean of all spectrophotometric determinations at $515 \mathrm{~m} \mu$ with the bars denoting the standard error. 
TABLE IV

Oxidation of Glucose-1 $-{ }^{14} \mathrm{C}$, Glucose- $6-{ }^{14} \mathrm{C}$, and Formate- ${ }^{14} \mathrm{C}$ by Normal and CHS Leukocytes*

\begin{tabular}{|c|c|c|c|c|c|c|}
\hline Substrate & Subject $\ddagger$ & $\begin{array}{c}\text { Cell } \\
\text { preparation§ }\end{array}$ & $\begin{array}{c}\text { Number } \\
\text { experiments }\end{array}$ & $\begin{array}{c}\text { Incubation } \\
\text { time }\end{array}$ & Resting $\ddagger$ & Phagocytizingף \\
\hline & & & & $\min$ & \multicolumn{2}{|c|}{ nmoles substrate oxidized (mean $\pm \mathrm{SE}$ ) } \\
\hline \multirow[t]{7}{*}{ Glucose $-1-{ }^{14} \mathrm{C}$} & Normal (2) & Mixed & 3 & 30 & \multirow{3}{*}{$\begin{array}{c}62.6 \quad \pm 10.0 \\
131 \pm 24 \\
<0.10\end{array}$} & \multirow{3}{*}{$\begin{array}{c}169 \pm 28 \\
240 \\
>0.20\end{array}$} \\
\hline & CHS (2) & Mixed & 3 & 30 & & \\
\hline & & & $P$ value** & & & \\
\hline & Normal (2) & Mixed & 2 & 60 & \multirow{3}{*}{$\begin{array}{c}58.2 \quad \pm 7.3 \\
125 \pm 33 \\
<0.20\end{array}$} & \multirow{3}{*}{$\begin{array}{c}385 \pm 12.8 \\
391 \pm 105 \\
>0.20\end{array}$} \\
\hline & CHS (2) & Mixed & 2 & 60 & & \\
\hline & & & $P$ value & & & \\
\hline & CGD (2) & Mixed & $\begin{array}{c}3 \\
P \text { value }\end{array}$ & 60 & $\begin{array}{c}15.9 \pm 2.5 \\
<0.01\end{array}$ & $\begin{array}{c}18.2 \pm 2.2 \\
<0.001\end{array}$ \\
\hline \multirow[t]{3}{*}{ Glucose-6-14C } & Normal (4) & $\mathrm{PMN}$ & 4 & 60 & \multirow{3}{*}{$\begin{array}{c}1.95 \pm 0.37 \\
3.12 \pm 0.56 \\
>0.10\end{array}$} & $6.23 \pm 2.20$ \\
\hline & CHS (2) & $\mathrm{PMN}$ & 4 & 60 & & $5.40 \pm 0.75$ \\
\hline & & & $P$ value & & & $>0.20$ \\
\hline \multirow[t]{4}{*}{ Formate- ${ }^{14} \mathrm{C}$} & Normal (8) & Mixed & 12 & 60 & \multirow{4}{*}{$\begin{array}{c}0.17 \pm 0.04 \\
0.28 \pm 0.09 \\
>0.20 \\
0.046 \pm 0.01 \\
<0.05\end{array}$} & $0.53 \pm 0.10$ \\
\hline & CHS (3) & Mixed & 7 & 60 & & $0.72 \pm 0.19$ \\
\hline & & & $P$ value & & & $>0.20$ \\
\hline & CGD (2) & Mixed & $\begin{array}{c}7 \\
P \text { value }\end{array}$ & 60 & & $\begin{array}{c}0.081 \pm 0.01 \\
<0.01\end{array}$ \\
\hline
\end{tabular}

* For studies of glucose- ${ }^{14} \mathrm{C}$ oxidation reaction mixtures $(2 \mathrm{ml})$ contained $5 \times 10^{6}$ phagocytes in $25 \%$ AB serum in $\mathrm{HBSS}$ with $0.5 \mu \mathrm{Ci}$ and $11.2 \mu$ moles of glucose. Formate- ${ }^{14} \mathrm{C}$ oxidation was measured in mixtures $(2.5 \mathrm{ml})$ containing $10 \times 10^{6}$ phagocytes, $20 \%$ AB serum in HBSS with $0.5 \mu \mathrm{Ci}$, and 250 nmoles of sodium formate. Phagocytosis was initiated by the addition of polystyrene latex particles and the mixtures were incubated for the times noted with trapping of ${ }^{14} \mathrm{C}-\mathrm{O}_{2}$ and counting as per text.

$\ddagger$ Numbers in parentheses refer to different subjects studied.

$\S$ Mixed cells refer to those obtained by dextran sedimentation (for differential counts see text). PMN were obtained by centrifugation on Ficoll-Hypaque.

$\|$ Amount of substrate oxidized to ${ }^{14} \mathrm{C}-\mathrm{O}_{2}$ by nonphagocytizing cells.

II Amount of substrate oxidized to ${ }^{14} \mathrm{C}-\mathrm{O}_{2}$ by cells ingesting polystyrene latex particles.

** Two sample $t$ test.

$9 \mathrm{~A}$ and $\mathrm{B}$ ). In some areas an occasional giant lysosome could be found apparently extruding its contents into a phagocytic vacuole, with corresponding alteration in the appearance of the bacteria. By $60 \mathrm{~min}$ of incubation these differences were less distinct. In normal cells peroxidase-positive granules were rarely seen in the cytoplasm and bacteria were collected within one or two vacuoles which contained peroxidase activity in each section examined (Fig. 9C). In CHS granulocytes giant lysosomes were frequently found which did not appear to have any connection with phagocytic vacuoles (Fig. 9D); however, in most sections a greater number of vacuoles contained peroxidase activity.

\section{DISCUSSION}

The most significant abnormality in function uncovered in the present investigations for phagocytes obtained from three patients with the CHS was an alteration in the rate of killing of several different classes of bacteria. Comparison with leukocytes obtained from two males with sex-linked CGD indicated that in contrast to the bactericidal defect for catalase-positive organisms found in these subjects (28), both catalase-positive ( $S$. aureus, $S$. marscescens, and $E$. coli) and catalase-negative (Group D streptococcus and pneumococci) bacteria were inactivated at abnormal rates by $\mathrm{CHS}$ cells. This defect in killing was most pronounced in the first $20 \mathrm{~min}$ of contact between CHS leukocytes and bacteria; thereafter bactericidal rates increased, a finding which further distinguished the CHS from the CGD leukocytes. The magnitude and duration of the defects observed for the CHS cells varied with the organism studied and were most marked for $S$. aureus and least so for $E$. coli. This pattern corresponds to the bacteria most frequently implicated in infections in these patients, with staphylococci having accounted for $65.7 \%$ of the 51 infectious episodes observed over a $3 \frac{1}{2}$ yr observation period in our subjects (9).

Previous data available on the bactericidal capabilities of CHS cells has been limited and seemingly at variance with our findings. For instance, employing a technique in which antibiotics are added to the medium 15 min after mixing cells and bacteria with sampling of the suspensions for surviving bacteria at 1 and $3 \mathrm{hr}$, 


\section{TABLE V}

Oxidation of Glucose-1-14 C by Normal and CHS Leukocytes Obtained by Centrifugation on Ficoll-Hypaque*

\begin{tabular}{llcccc}
\hline Subject $\neq$ & \multicolumn{1}{c}{ Cell prep§ } & $\begin{array}{c}\text { Number } \\
\text { experiments }\end{array}$ & $\begin{array}{c}\text { Incubation } \\
\text { time }\end{array}$ & Resting! & Phagocytizing T \\
\hline & & & min & nmoles substrate oxidized (mean \pm SE) \\
Normal (6) & PMN & 6 & 30 & $58.1 \pm 8.0$ & $168 \pm 48.2$ \\
CHS (2) & PMN & 6 & 30 & $117 \pm 11.3$ & $135 \pm 31.4$ \\
& & & $P$ value** & $<0.01$ & $>0.20$ \\
Normal (6) & PMN & 6 & 60 & $58.9 \pm 14.4$ & $206 \pm 26.2$ \\
CHS (2) & PMN & 4 & 60 & $196 \pm 25.7$ & $250 \pm 53.2$ \\
& & & $P$ value & $<0.001$ & $>0.20$ \\
Normal (5) & Monos (suspension) & 5 & 60 & $27.2 \pm 6.4$ & $161 \pm 25.6$ \\
CHS (2) & Monos (suspension) & 2 & 60 & $93.9 \pm 20.2$ & 187 \\
& & 4 & $P$ value & $<0.01$ & $>0.20$ \\
Normal (4) & Monos (adherent) & & 60 & $11.5 \pm 3.0$ & $130 \pm 4.4$ \\
CHS (2) & Monos (adherent) & 2 & 60 & $31.9 \pm 2.4$ & $180 \pm 6.0$ \\
& & & $P$ value & $<0.02$ & $<0.01$ \\
\hline
\end{tabular}

* For details of the separation procedure see text. All incubation mixtures consisted of $5 \times 10^{6}$ phagocytes in $2 \mathrm{ml}$ HBSS $-25 \% \mathrm{AB}$ serum with $0.5 \mu \mathrm{Ci}$ and $11.2 \mu$ moles of glucose. Phagocytosis was initiated by the addition of $2 \times 10^{9}$ polystyrene latex particles and ${ }^{14} \mathrm{C}-\mathrm{O}_{2}$ trapped and counted as noted in text. $\ddagger$ Numbers in parentheses refer to different subjects studied.

$\S P M N$ were in suspension at a concentration of $5 \times 10^{6} / \mathrm{ml}$. "Monos (suspension)" were mixtures of monocytes and lymphocytes (approximately $30 \%$ and $70 \%$, respectively) maintained in suspension similar to PMN at a concentration of $5 \times 10^{6}$ monocytes $/ \mathrm{ml}$. "Monos (adherent)" were obtained by layering mixtures of monocytes $\left(5 \times 10^{6}\right)$ and lymphocytes in the 25 -ml Erlenmeyer reaction flask for $90 \mathrm{~min}$, and then washing off the nonadherent lymphocytes and platelets with HBSS before measurement of glucose-1 $1{ }^{14} \mathrm{C}$ oxidation.

\| Nonphagocytizing cells.

T Cells which were incubated with polystyrene latex particles.

** Two sample $t$ test.

Windhorst et al. were unable to find an abnormality of killing of staphylococci in two experiments on one patient (8). As noted in Fig. 4, however, the use of such sampling times might have missed the delay in intracellular killing, the most consistent feature of our results. In another unpublished investigation using tech-

TABLE VI

Iodination of TCA-Precipitable Protein by CHS, CGD, and Normal Leukocytes*

\begin{tabular}{llccc}
\hline Subject $¥$ & Addition & $\begin{array}{c}\text { No. } \\
\text { experiments }\end{array}$ & Resting cells & $\begin{array}{c}\text { Phagocytizing } \\
\text { cells }\end{array}$ \\
\hline & & & nmoles & nmoles \\
Normal (5) & None & 5 & $0.139 \pm 0.034 \S$ & $0.534 \pm 0.084$ \\
CHS (2) & None & 3 & $0.791 \pm 0.274$ & $1.499 \pm 0.267$ \\
$P$ value $\|$ & & & $<0.01$ & $<0.01$ \\
Normal (3) & $1 \mathrm{mM}$ azide & 3 & $0.018 \pm 0.009$ & $0.012 \pm 0.001$ \\
CHS (2) & $1 \mathrm{~mm}$ azide & 2 & 0.018 & $0.076 \pm 0.036$ \\
CGD (2) & None & 2 & $0.038 \pm 0.018$ & $0.072 \pm 0.035$ \\
$P$ value & & & $<0.05$ & $<0.01$ \\
\hline
\end{tabular}

* Reaction mixtures consisted of $5 \times 10^{6} \mathrm{PMN}, 20$ nmoles and $0.2 \mu \mathrm{Ci} \mathrm{Na}{ }^{125} \mathrm{I}$ with or without $1 \times 10^{8}$ heat-killed $S$. aureus and $1 \mathrm{~mm}$ azide in $10 \%$ AB serum-HBSS incubated for $60 \mathrm{~min}$ at $37^{\circ} \mathrm{C}$. Leukocytes were obtained by dextran sedimentation (for differential counts see text).

$\ddagger$ Numbers in parentheses refer to number of different individuals studied.

$\S$ Mean \pm SE of nmoles iodide fixed to protein.

|| Two sample $t$ test. 


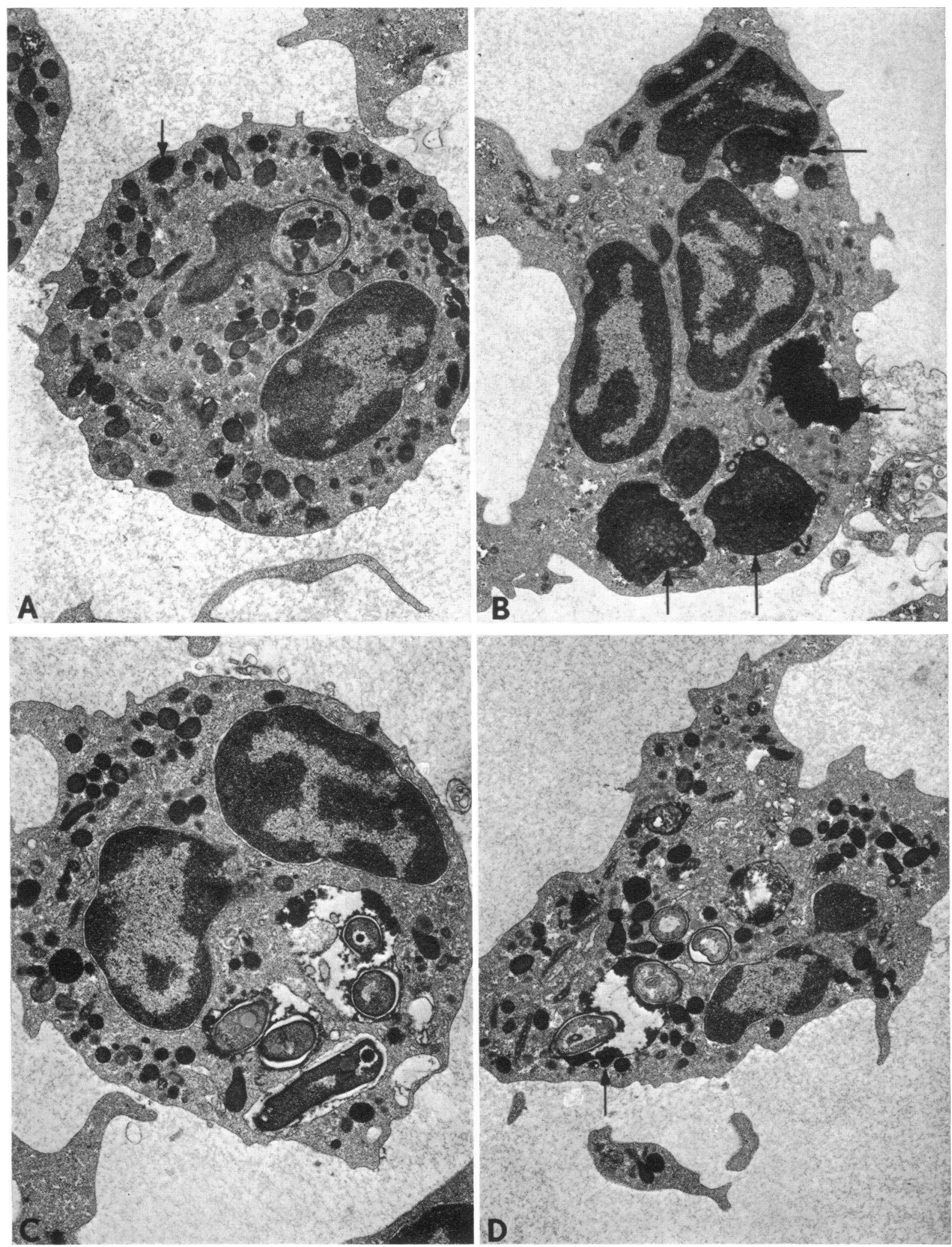


niques similar to ours, Quie found an impairment in killing of $S$. aureus by leukocytes from one $\mathrm{CHS}$ patient in the range reported here; however, the experiments could not be repeated because of the patient's severe neutropenia and early demise. ${ }^{4}$ A third study on another patient has reported impairments in killing of $S$. aureus and $S$. marcescens similar to the findings reported here (31). Recently, Davis reported that leukocytes from CHS cattle, but not mink, had defective killing of $S$. aureus and B. subtilis (4).

Because of the kinetics of the abnormal killing shown by the CHS cells, it became important to establish that the delay was not due to diminished phagocytic rates. Microscopic studies indicated that at the end of a 20 min incubation period CHS granulocytes and monocytes participated in the phagocytic process in numbers similar to normal, and the content of intracellular organisms appeared the same. A better measure of the rate of bacteria ingestion was afforded by the use of radiolabeled organisms in which the phagocytic activity by the entire cell population could be frequently sampled. In preliminary experiments it was determined that the amount of radioactivity associated with the cell pellet correlated closely with the number of intracellular bacteria. It was then demonstrated that the uptakes by both male patients were similar to normal controls, leading to the conclusion that the marked delay in killing observed over the first 20 min could only be due to abnormal intracellular inactivation. Similar data on ingestion rates was obtained on one CGD subject confirming previous observations of their normal phagocytic capabilities (21).

Due to the neutropenia of the CHS patients the mixed cell populations obtained by dextran sedimentation differed from normal not only in their diminished number of granulocytes but also in their larger percentage of monocytes and lymphocytes. The numbers of eosinophils, on the other hand, were similar in both patient and normal groups. The question then arises as to whether the larger number of monocytes in the CHS phagocytic suspensions could cause an apparent impairment of bactericidal activity because of their reduced phagocytic capabilities compared to granulocytes (32). Several points argue strongly against this conclusion. First, although the percentage of monocytes was greater than normal, the number of granulocytes in the CHS cell preparations outweighed monocytes by at least five to one in all studies. Second, the kinetics of phagocy-

${ }^{4}$ Quie, P. G. Personal communication. tosis by the mixed cell populations was found to be normal as noted above. Third, the data obtained from the CHS female, who was significantly more neutropenic than both males, was identical to the males. Finally, when CHS granulocytes and monocytes were obtained separately from Ficoll-Hypaque gradients and matched in percentages identical to normal cells, the abnormalities observed for the mixed cell population persisted. Granulocytes were found to ingest ${ }^{14} \mathrm{C}$-labeled $S$. aureus at rates equivalent to normal, yet had a diminished rate of killing which persisted over $2 \mathrm{hr}$. Monocytes were likewise found to have normal rates of bacterial ingestion whether maintained in suspension with lymphocytes or allowed to adhere to a plastic surface and washed free of the latter cells. In contrast to granulocytes, however, kill rates for $S$. aureus were impaired over the 1 st hr of incubation only.

Having demonstrated impaired bactericidal activity by $\mathrm{CHS}$ leukocytes in a pattern that differed from the CGD cells it became of interest to further compare the activities of these cells in metabolic studies important to the bactericidal process. In contrast to the CGD leukocytes (21) and similar to studies previously reported for mink and cattle with the CHS (5), it was quickly determined that $\mathrm{CHS}$ phagocytes were capable of a respiratory "burst" after phagocytosis (33). Measurements of the oxidation of glucose- $1-{ }^{14} \mathrm{C}$, glucose-6${ }^{14} \mathrm{C}$ and formate $-{ }^{14} \mathrm{C}$ were also similar to normal after phagocytosis at two incubation times, indicative of normally functioning pentose shunt and Krebs' cycle pathways and normal production of hydrogen peroxide (23). As expected, glucose- $1-{ }^{14} \mathrm{C}$ and formate oxidation by the CGD cells was significantly diminished from normal (21). CHS leukocytes were also capable of utilizing peroxide and myeloperoxidase to enzymatically iodinate intracellular protein (24) with activities that exceeded similar numbers of normal granulocytes in both the resting and the phagocytizing state. The addition of sodium azide to the incubation mixtures resulted in equivalent suppression of normal and CHS iodination to the range seen with untreated CGD cells (25).

In addition to the increased iodination, glucose $-1-{ }^{14} \mathrm{C}$ oxidation by nonphagocytizing $\mathrm{CHS}$ leukocytes was also significantly greater than normal. When this was investigated further by comparing glucose $-1-{ }^{14} \mathrm{C}$ oxidation activities of cells separated by the Ficoll-Hypaque technique, both granulocytes and monocytes exhibited this abnormality. In addition, monolayers of CHS monocytes had significantly higher than normal postphagocytic glucose $-1-{ }^{14} \mathrm{C}$ oxidation that could not be

FIGURE 8 Electron micrographs of granulocytes histochemically stained for peroxidase activity. Panel A is a normal and panel B a CHS granulocyte without ingested particles. Arrows point to peroxidase-positive lysosomes. Panels $\mathrm{C}$ and $\mathrm{D}$ are representative sections of normal granulocytes 15 min after mixing with $S$. aureus. Note the dark staining peroxidase activity in phagosomes surrounding bacteria and evidence of active degranulation (arrow, panel D). 


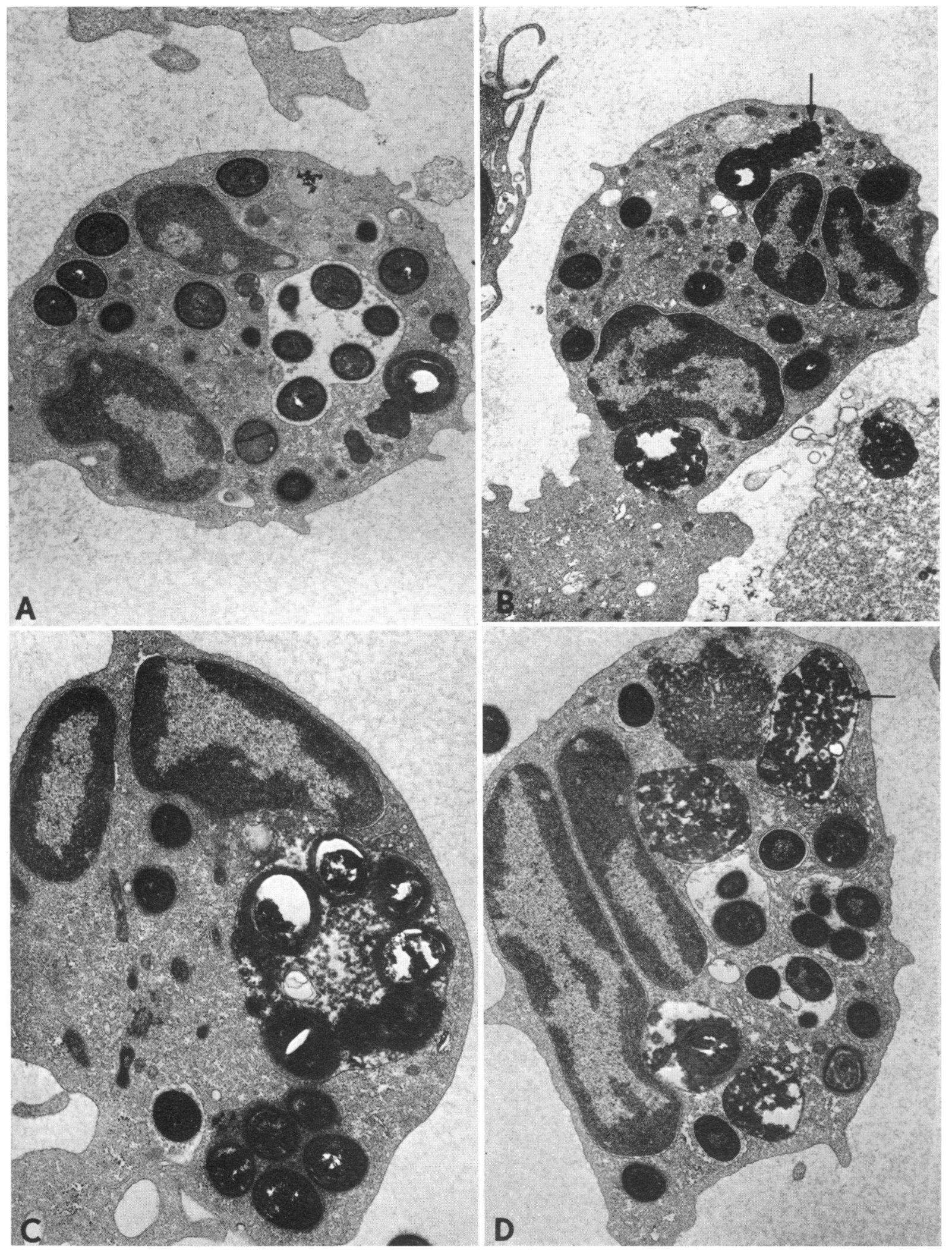


explained by different cell numbers. These findings are paralleled by the earlier observation of increased sphingolipid turnover in peripheral leukocytes from the CHS patients (34). What the significance of these findings is in relation to membrane turnover or inherent phagocytic capabilities (35) of these cells is indeterminate. It is of interest that in another series of studies (36) CHS leukocytes were capable of ingesting greater amounts of a paraffin oil emulsion than normal cells. Both the increased iodination of protein and the exaggerated oxidation of glucose- $1-{ }^{14} \mathrm{C}$ by nonphagocytizing CHS leukocytes could be explained by elevated peroxide production $(24,37)$. In keeping with this, the oxidation of formate- ${ }^{14} \mathrm{C}$ by these cells was also higher on the average than normal; however the difference between the means was not statistically significant due to experimental variability. Similarly, the oxidation of glucose- $6-{ }^{14} \mathrm{C}$ was increased in resting $\mathrm{CHS}$ leukocytes in some but not all experiments and the means were not significantly different.

As initially suggested by the finding of abnormal killing of both catalase-positive and catalase-negative bacteria, these observations indicate that metabolic abnormalities related to the generation of hydrogen peroxide are not involved in the pathogenesis of the defect seen in the CHS cells. Previous data obtained in our laboratory have indicated that CHS granulocytes contain reduced activities of the primary lysosomal enzymes myeloperoxidase and $\beta$-glucuronidase (38) ; however, the degree of reduction of peroxidase is clearly not enough to impair intracellular iodination as noted above. Therefore, it appears unlikely that peroxidase deficiency, per se, is responsible for the observed findings.

Attention was then directed to the manner in which the abnormal lysosomes participate in the normal postphagocytic chain of events. Similar to previously reported findings for mink and cattle (5), the giant lysosomes were noted by light and phase microscopy to remain apparently intact for prolonged periods of time after phagocytosis. A cytochemical technique in conjunction with electron microscopy was employed to better observe the manner in which peroxidase is delivered into phagocytic vacuoles in CHS cells. As noted previously (39), almost all peroxidase activity within CHS granulocytes was localized to the giant lysosomes.
Furthermore, after bacterial ingestion the delivery of peroxidase activity appeared spotty and inefficient when compared to normal, with many phagosomes devoid of this activity $15 \mathrm{~min}$ after the start of ingestion. As a corollary, the appearance of most of the bacteria within the CHS granulocytes was strikingly different from normal in that many staphylococci retained details of morphology similar to noningested organisms. In some sections giant lysosomes were seen discharging their contents into scattered phagosomes and in these bacterial morphology was altered similar to that seen in normal cells. By $60 \mathrm{~min}$, more vacuoles contained peroxidase activity, but in many sections giant granules were observed to remain apparently intact and without relationship to phagocytic vesicles. These observations suggest that the increased delivery of peroxidase into more phagocytic vacuoles with time either through delayed degranulation or fusion of peroxidase-negative with peroxidase-positive vacuoles might be responsible for the increase in bactericidal rates observed in the CHS cells. In this regard, it is of interest that the kinetics of the bactericidal process in CHS leukocytes bears a resemblance to that seen in leukocytes from an individual with myeloperoxidase deficiency (40). Whether the delay in killing in the first $20 \mathrm{~min}$ is due to a lack of peroxidase or some other bactericidal substance in the majority of phagosomes within CHS cells can only be speculated, however. Biochemical support for these morphological observations by measurement of intraphagosomal activity of two enzymes associated with primary lysosomal granules (peroxidase and $\beta$-glucuronidase) (41) has been obtained employing a technique to isolate phagocytic vesicles (42) and is the subject of another report (36).

These studies provide evidence that in addition to impaired chemotactic responses and neutropenia, delayed inactivation of intracellular bacteria, in particular staphylococci, might play a role in the pathogenesis of recurrent skin and sinopulmonary infections characteristic of patients with the CHS. Furthermore, the contrasting patterns and kinetics of the bactericidal defects exhibited by the CHS and CGD leukocytes as well as their differing metabolic properties illustrate the multiplicity of factors involved in leukocyte antimicrobial mechanisms and the pleiomorphic nature of inherited defects of leukocyte function.

FIGURE 9 Electron micrographs of granulocytes which have phagocytized $S$. aureus and are histochemically stained for peroxidase. Panels A and B depict sections of CHS granulocytes taken $15 \mathrm{~min}$ after mixing with staphylococci. Note the lack of peroxidase activity around most phagosomes with the exception of those into which giant lysosomes (arrows) appear to be discharging their contents. Panel $\mathrm{C}$ is a normal granulocyte $60 \mathrm{~min}$ after mixing with staphylococci showing phagosomal fusion with peroxidase activity in the phagosomes and a lack of peroxidase-positive granules in the cytoplasm. Panel D is a CHS granulocyte at the same time interval which depicts the persistence of structurally intact peroxidase-positive giant lysosomes (arrows). Peroxidase activity can be seen in some, but not all, phagosomes. 


\section{ACKNOWLEDGMENTS}

The authors are indebted to Dr. David Alling for help with statistical analyses and to Dr. Sheldon M. Wolff for support, encouragement, and critical evaluation of this manuscript.

\section{REFERENCES}

1. Padgett, G. A. 1968. The Chediak-Higashi syndrome. Advan. Vet. Sci. $12: 239$.

2. Lutzner, M. A., C. T. Lowrie, and H. W. Jordan. 1967. Giant granules in leukocytes of the beige mouse. $J$. Hered. $58: 299$.

3. Kritzler, R. A., J. Y. Terner, J. Lindenbaum, J. Magidson, R. Williams, R. Preisig, and G. B. Philips. 1964. Chediak-Higashi syndrome. Cytologic and serum lipid observations in a case and family. Amer. J. Med. 36: 583

4. Davis, W. C. 1970. Leukocyte dysfunction in an animal homologue of the Chediak-Higashi syndrome of man. Fed. Proc. 29: 1379. (Abstr.)

5. Padgett, G. A. 1967. Neutrophilic function in animals with the Chediak-Higashi syndrome. Blood J. Hematol. 29: 906.

6. Saraiva, L. G., M. Azevedo, J. M. Correa, G. Carvalho, and J. D. Prospero. 1959. Anomalous panleukocytic granulation. Blood J. Hematol. 14: 1112.

7. Page, A. R., H. Berendes, J. Warner, and R. A. Good. 1962. The Chediak-Higashi syndrome. Blood J. Hematol. $20: 330$.

8. Windhorst, D. B., J. G. White, A. S. Zelickson, C. C. Clawson, P. B. Dent, B. Pollara, and R. A. Good. 1968. The Chediak-Higashi anomaly and the Aleutian trait in mink: homologous defects of lysosomal structure. Ann. N. Y. Acad. Sci. 155: 818.

9. Wolff, S. M., D. C. Dale, R. A. Clark, R. K. Root, and H. R. Kimball. 1972. The Chediak-Higashi syndrome. Ann. Intern. Med. 76: 293.

10. Blume, R. S., J. M. Bennett, R. A. Yankee, and S. M. Wolff. 1968. Defective granulocyte regulation in the Chediak-Higashi syndrome. N. Engl. J. Med. 279: 1009.

11. Clark, R., and H. Kimball. 1971. Defective granulocyte chemotaxis in the Chediak-Higashi syndrome. J. Clin. Invest. 50: 2645.

12. Weary, P. E., and A. S. Bender. 1967. Chediak-Higashi syndrome with severe cutaneous involvement. Arch. Intern. Med. 119 : 382.

13. Moran, T. J., and J. M. Estevez. 1969. Chediak-Higashi disease. Morphologic studies of a patient and her family. Arch. Pathol. 88 : 329.

14. Ward, P. A., and R. J. Schlegel. 1969. Impaired leucotactic responsiveness in a child with recurrent infections. Lancet. 2: 344.

15. Bellanti, J. A., B. E. Cantz, and R. J. Schlegel. 1970. Accelerated decay of glucose-6-phosphate dehydrogenase activity in chronic granulomatous disease. Pediat. Res. 4: 405 .

16. Fallon, H. J., E. Frei, J. D. Davidson, J. S. Trier, and D. Burk. 1962. Leukocyte preparations from human blood: evaluation of their morphologic and metabolic state. J. Lab. Clin. Med. 62: 779.
17. Mickenberg, I. D., R. K. Root, and S. M. Wolff. 1970. Leukocytic function in acquired hypogammaglobulinemia. J. Clin. Invest. 49: 1528.

18. Boyum, A. 1968. Isolation of mononuclear cells and granulocytes from human blood. Scand. J. Clin. Lab Invest. (Suppl.) : 77.

19. Lowry, O. H., N. J. Rosebrough, A. L. Farr, and R. J. Randall. 1951. Protein measurement with the Folin phenol reagent. J. Biol. Chem. 193: 265.

20. Hirsch, J. G., and B. Strauss. 1964. Studies on heat labile opsonin in rabbit serum. J. Immunol. $92: 145$.

21. Holmes, B., P. G. Quie, D. B. Windhorst, and R. A. Good. 1966. Fatal granulomatous disease of childhood: inborn abnormality of phagocytic function. Lancet. 1: 1225.

22. Lehrer, R. I., and M. J. Cline. 1969. Interaction of Candida albicans with human leukocytes and serum. $J$. Bacteriol. 98 : 996.

23. Iyer, G. Y. N., M. F. Islam, and J. H. Quastel. 1961. Biochemical aspects of phagocytosis. Nature (London). 192: 535 .

24. Klebanoff, S. J. 1967. Iodination of bacteria: a bactericidal mechanism. J. Exp. Med. 126: 1063.

25. Klebanoff, S. J. 1970. Myeloperoxidase: contribution to the microbicidal activity of intact leukocytes. Science (Washington). 169: 1095.

26. Baehner, R. L., and D. G. Nathan. 1968. Quantitative nitroblue tetrazolium test in chronic granulomatous disease. N. Engl. J. Med. 278: 971.

27. Graham, R. C., and J. M. Karnovsky. 1966. The early stages of absorption of injected horseradish peroxidase in the proximal tubules of mouse kidney: ultrastructural cytochemistry by a new technique. J. Histochem. Cytochem. 14: 29.

28. Mandell, G. L., and E. W. Hook. 1969. Leukocyte bactericidal activity in chronic granulomatous disease: correlation of bacterial hydrogen peroxide production and susceptibility to intracellular killing. J. Bacteriol. 100: 531 .

29. Holmes, B., A. R. Page, and R. A. Good. 1967. Studies of metabolic activity of leukocytes with a genetic abnormality of phagocytic function. J. Clin. Invest. 46: 1422.

30. Pincus, S. H., and S. J. Klebanoff. 1971. Quantitative leukocyte iodination. N. Engl. J. Med. 284: 744.

31. Mallen, M. S., M. E. A. Chavarria, and E. S. R. Pastor. 1970. Comportamiento antibacteriano de los leucocitos en sujetos normales, en la enfermedad de Chediak-Higashi y en la anomalia de Pelger-Huet. Rev. Invest. Salud Publica. 30: 5 .

32. Cline, M. J., and R. I. Lehrer. 1968. Phagocytosis by human monocytes. Blood J. Hematol. 32: 423.

33. Karnovsky, M. L. 1962. Metabolic basis of phagocytic activity. Physiol. Rev. $42: 143$

34. Kanfer, J. N., R. S. Blume, R. A. Yankee, and S. M. Wolff. 1968. Alteration of sphingolipid metabolism in leukocytes from patients with the Chediak-Higashi syndrome. N. Engl. J. Med. 279: 410.

35. Axline, S. G. 1970. Functional biochemistry of the macrophage. Seminars Hematol. 7 : 142.

36. Stossel, T. P., R. K. Root, and M. Vaughn. 1972. Phagocytosis in chronic granulomatous disease and the Chediak-Higashi syndrome. N. Engl. J. Med. 286: 120. 
37. Reed, P. W. 1968. Glutathione and the hexose monophosphate shunt in phagocytizing and hydrogen peroxidetreated rat leukocytes. J. Biol. Chem. 244: 2459.

38. Kimball, H. R., and G. Ford. 1970. Granulocyte 1ysosomal enzymes in the Chediak-Higashi syndrome (CHS). Clin. Res. 18: 407.

39. Sadan, N., D. Yaffe, L. Rozenszajn, H. Adar, B. Soreker, and P. Efrati. 1965. Cytochemical and genetic studies in four cases of the Chediak-Higashi Steinbrinck syndrome. Acta Haematol. 34: 20.
40. Lehrer, R. I., J. Hanifin, and M. J. Cline. 1969. Defective bactericidal activity in myeloperoxidase-deficient human neutrophils. Nature (London). 223: 78.

41. Baggiolini, M., J. Hirsch, and C. deDuve. 1969. Resolution of granules from rabbit heterophile leukocyte populations by zonal centrifugation. J. Cell Biol. 40: 529 .

42. Stossel, T. P., T. D. Pollard, R. J. Mason, and M. Vaughn. 1971. Isolation and properties of phagocytic vesicles from polymorphonuclear leukocytes. J. Clin. Invest. 50: 1745 . 